\title{
ROOTS OF THE CZECHOSLOVAK SKINHEADS: DEVELOPMENT, TRENDS AND POLITICS
}

\author{
JOSEF SMOLÍK, PETR NOVÁK
}

\begin{abstract}
This article focuses on the roots and ideological sources of the Czechoslovak skinheads. It describes the development of this subculture from the 1980s until the end of the joint Czechoslovak state. It looks at the history of this subculture together with its development trends in the 1990s. The relationship between the skinheads and politics clearly belongs in this account as it was the source of the distinctions between the various groups in the subculture. The themes that were typical of the skinhead subculture are introduced together with an exploration of how they later transformed in line with the political requirements of this part of the youth subculture. This subsequently led to support for nationalist political parties. The article is of a descriptive and analytical nature, and is an attempt to grasp the key processes taking place among the adolescents who identified with the skinhead subculture. Contemporary magazines are the basis of an analysis of the key themes in skinhead subculture in the early 1990s.
\end{abstract}

Key words: skinheads; political attitudes; politics, racism; violence

\section{Introduction}

In the international literature, research into the skinhead subculture is conducted from within sociology, psychology and political science, with the latter mainly focusing on the political attitudes of the skinhead subculture, its support for radical political parties, and specific themes such as racism, anti-Semitism and violence towards minorities (Hamm, 1993; Peknušiaková, 2014; Ridgeway, 1990; Wood, 1999; Youngová, 2017). The skinhead subculture is also often connected with radical politics, ideologies and football violence (Charvát, 2007; Youngová, 2017).

The skinhead subculture began forming in Czechoslovakia in the late 1980s. ${ }^{1}$ This subculture was long perceived by politicians and part of the general public to be controversial and violent; it has also been identified with racism, radicalism, extremism and a policy of violence. The skinhead subculture is associated with antisocial or risk behaviour.

\footnotetext{
1 In Czechoslovakia the abbreviated term "skins" is also used, in the journalist jargon to mean "shaved heads" or "bald heads" (Smolík, 2016, p. 140).
} 
Sometimes this subculture is-erroneously—viewed as necessarily having a connection to Neo-Nazism or extreme right-wing politics (Sobotková Nielsen et al., 2014).

This article will mainly focus on the roots of this subculture in Czechoslovakia in the 1980s. The 1980s was its formative period, and is often connected with extreme right-wing politics (Charvát, 2007). This is one of the reasons why the subculture was the subject of police reports, discussed in the media and the subject of political statements (Vávra, 2017).

Views on the development of the skinhead culture (both in Czechoslovakia and abroad) in the existing resources and of those involved differ considerably. The reason is the underlying ideological dispute about the racial origins and essence of the subculture (Smolík, 2017).

\section{Methods}

The basic method applied in this study is an in-depth literature review on the skinhead theme from the late 1980s to the mid-1990s in Czechoslovakia and then later in the Czech Republic. The thematic analysis will include selected skinhead zines from the late 1980s to the mid1990s. These are not analysed using content analysis but through an exploratory analysis (Hendl, 2005). The output of this analysis is the "story of a subculture" and a description of various groups that formed within it during the 1990s.

\section{Skinheads in Czechoslovakia: Roots}

The skinhead subculture spread across Central and Eastern Europe in the late 1980s, peaking in the 1990s (Gřivna, Scheinost, \& Zoubková et al., 2014; Kupka, Laryš, \& Smolík, 2009; Vávra, 2017).

Skinheads appeared not only in the Czechoslovak Socialist Republic and in the People's Republic of Hungary, but also, significantly, in the German Democratic Republic, beginning in the early $1980 \mathrm{~s}^{2}$. The skinhead movement took off among young people in the new federal states following the unification of Germany in 1990, and skinheads committed violent crimes (Botsch, 2012; Mikulčíková, 2010). The German media of the period covered skinhead bands (such as Böhse Onkelz) as well as their fans, who were automatically labelled Neo-Nazis, bullies and criminals (see for example Marshall, 1994).

Although in the latter half of the 1980s, rock and in particular heavy metal music had the most appeal among the young Czechoslovak working class, punk rock was the main expression of provocation and resistance against the regime of the time. It is interesting to note that most of the first Czechoslovak skinheads had their roots in the punk subculture.

The first members of the skinhead subculture appeared in Czechoslovakia at the beginning of the latter half of the 1980s. Skinheads were first mentioned in the Czechoslovak Socialist Republic in an article in the fortnightly 100+1 zahraniční zajímavost $(100+1$ fun facts from abroad), from the German magazine Stern.

Consequently, some claim this is the reason this subculture appeared in Czechoslovakia (Bihariová, 2011).

2 In the late 1980s the former East Germany recorded 1,067 individuals in the 16-25 age group as declaring an affinity to the skinhead subculture (Mikulčíková, 2010). 
The article outlined the skinhead subculture in Great Britain, West Germany, Spain, Belgium, France, Switzerland and Greece. The extreme-right of the subculture was linked to extreme right-wing political parties (for example the National Front in Britain, the National Democratic Party of Germany in West Germany or the Liberal German Labour Party) in various countries, and with negative phenomena or a particular socio-economic status (Kromschröder, 1986).

From the early 1990s, the skinhead subculture, especially its racist strand, was a major issue not only for the media but for the police as well. The materials of the Presidium of the Police of the Czech Republic of 1993 for example record the "increasing aggressiveness of the skins" and that the "nature of their crimes is more serious with increasing material property damage".

Racist hatred of the skins was initially also focused against the Vietnamese and, according to information held by the reporting service, the skins were engaged in aggression against citizens of Bulgaria, Romania and in one case against a native of Egypt (Police Presidium of the Czech Republic, 1993, p. 6).

As correctly noted by Š. Danics (2002), the skinheads of that period were characterised by a strong group identity, suppressed individualism and great efforts to stand out in appearance and the use of provocative symbolism. The group identity was an adopted one, for the Czechoslovak skinheads copied their idols in Great Britain, Germany, France and the Netherlands.

It is difficult to accurately identify the first Czechoslovak skinhead or skinhead gang (Vávra, 2017). Individuals who took their inspiration from the skinhead subculture, discovered mainly through snippets of information from communist propaganda about the increasing violence and Neo-Fascism in western countries and through youth magazines imported across the Iron Curtain (for example by parents or friends), often did so accidentally, slowly and on their own. In the beginning, the information (or interpretations) about the skinheads (and often also about punk) was not very objective and sometimes did not reflect the reality.

One of the first music bands to publicise the skinhead subculture at that time was the punk rock group Heroes of the New Front. This is how P. Štěpán described the sources of information available about skinheads:

First there were various official magazines published in Czechoslovakia, Saturday newspaper supplements etc. In them the skinheads were often mentioned together with punk, for both were new youth movements, that is, western youth movements. The articles included photos of shaven-headed boys in bombers, military boots and jeans with braces. The articles were obviously biased and referred to the "decadent" western society, and everything was set in the context of the increasing violence and crisis in the capitalist system. Later we could hear recordings by skin bands such as Screwdriver or Cockney Rejects. Their music was called Oi!, or sometimes Oi rock or Oi punk. Those were the first pieces of information we had. It was not our main interest, we just wanted to be informed (Smolík, 2017, p. 142).

It was the Oi punk music genre which shaped the opinions and attitudes of the first Czechoslovak skinheads. This music genre can be defined as aggressive guitar music based on punk rock, which is the reason why Oi! is sometimes called street punk (even by its 
protagonists). This music style developed at the end of the 1970s when some foreign punk bands played for audiences containing skinheads, which was one of the reasons for the pretence for violence among these subcultures (see Gilbert, 2007; Worley, 2013).

Oi was rejected by the public abroad, with its references to racism and extreme rightwing politics (Marshall, 1994). Some of the music bands (typically Blitz, One Way System) saw no distinction between punk and the emerging skinhead style, and so their fans included both punk rockers and skinheads (Glasper, 2010; Worley, 2013).

Further sources of information about skinheads included direct experience of the subculture by Czech punkers and Czech hippies fighting Polish skinheads, for example at the Warsaw festival of Róbrege in the summer of 1987 or at Jarocina a year later (Daniel, 2016).

At the end of the 1980s, the units of repression directed their attention at young people who listened to heavy metal music or who were involved in the music underground. In Czechoslovakia the racism and nationalism of the latter half of the 1980s was only marginally linked to punk rock. Nonetheless, the punk subculture gave rise to a number of pioneering Czechoslovak skinhead groups. Their members were responsive to the appeal of the aggressive ethos of the ostracised subculture, despite the puritan society of "goulash communism" that considered punk to be more provocative. However, the opportunity to commit and justify violence against Gypsies and foreign students or immigrant labour (from Cuba, Vietnam and other countries in the left-wing third world) whilst expressing anti-regime (anti-communist) attitudes encouraged the first followers to establish the Czechoslovak skinhead movement.

The more stable groups were formed in Prague, Liberec, North Bohemia, Pilsen, Brno and the Bohemian-Moravian Highlands. Before November 1989 there were about 70-90 weakly profiled skins in the Czech Lands (the Czech part of Czechoslovakia, now the Czech Republic) (Smolík, 2017; Vávra, 2017).

In the mid-1980s a band was formed in Liberec called Oi Oi Hubert Macháně, but the link between it and the skinhead subculture is not absolutely clear, for it saw itself as part of the punk subculture. The band performed songs with lyrics that are still popular today, such as "The White Beat" or "Hit the Negro on the Head", but the music would never appeal to the masses. Far more inspiring at this early stage of skinhead development and the Oi! style was the first real Czech skinhead band called Orlík, formed in Prague in late 1988 (Vaněk, 2010). Paradoxically enough, some of Orlík's members (D. Landa and D. Matásek) belonged to the intellectual rather than labouring classes. D. Landa studied music and drama at the Prague Conservatory. In 1987 Karel Smyczek cast D. Landa in the character of an aggressive football hooligan in his film called Proč? [Why?], where he superbly exploited his experiences of Viktoria Žižkov matches, the Prague football club he supported (Charvát, 2007; Konáš, 2005). Being a member of Orlík led to D. Landa being labelled a fascist for the rest of his life, which he never actually was. Orlík was originally a garage band which did not hold back when attacking the regime. The discussions around D. Landa and the skinheads seem endless. One thing is certain, though, the Orlík band had a significant influence on adolescents in the early 1990s (Vávra, 2017).

Another figure in Orlík, D. Matásek, described the situation at the time in an interview given in 2014: 
When we started our band, we weren't thinking about ideology. But as our audiences radicalised, we understood that we would have to take a standpoint. And our standpoint was that we stopped, as we did not think it was good or sustainable. There are other groups in the skinhead movement and so, unfortunately, we began to be identified with the most extreme branch that had a neo-Nazi flavour. We didn't want to be seen in that context (Braunová, 2014, p. 7).

What was specific to the skinhead style in the Czech Republic was the strong role played by students and intellectuals (albeit while living the Bohemian pub life) in the first stages of the subculture development, in contrast to the purely working-class roots of the skinhead movements in Western Europe or the USA (Mareš, 2003; Smolík, 2006). Although later fans of Orlík were mainly manual workers or apprentices, and their opposing numbers from the student or more generally intellectual population may well have despised them, for at least up until the mid-2000s references to the working class had negative connotations in most Czech environments (Daniel, 2016).

Orlík had created an important basis for the initial ideological and musical characteristics of the skinhead subculture, contributing to the popularisation of the "skinhead cult" among young people (Gřivna, Scheinost, Zoubková et al., 2014). The mass development of the subculture came after 1989. By the spring of 1990, the first skinheads had already emerged in many parts of Czechoslovakia. The skinhead subculture then received a major boost in the release of the first record by Orlík (following the inclusion of two of their songs in a Punk and Oi! compilation) called Miloš Frýba for President, recorded and released by Monitor.

This record (and the CD version) sold several dozen thousand copies, as not only skinheads bought it. Their general popularity among young people caused some of the songs to become part of the nation's folklore. A second recording by Orlík dating from 1991 and called Demise was as popular as the previous one ${ }^{3}$, inspiring other skinhead bands, who, however, did not work with such prestigious music producers as Orlík did (except for Braník) (Daniel, 2016).

The raw anti-communism that was then compulsory not only among the subcultures but for all cultural leaders across the political spectrum was explained in lyrics by Orlík and the later acknowledged references to the lyrics of K. Kryl and the historic experience of the "Czech garden" being plundered by the Soviets (Daniel, 2016).

Like Orlík in the Czech Republic the Slovak band Krátky Proces (Short Process) contributed to the formation of the skinhead subculture in Slovakia. In the early 1990s Krátky Proces defined the basic principles and themes characteristic for adolescent Slovak skinheads. These included hatred of foreigners, Slovak nationalism and the idealisation of the Slovak Republic of 1939-1945. Krátky Proces inspired later bands such as D.M.S. or Cirhóza 88 (Cirrhosis 88) (Mareš \& Výborný, 2013).

Legendary events included the first purely skinhead festival held in Bzenec, South Moravia, in June 1991. This meeting of Czechoslovak skinhead bands featured Orlík, Braník, Valašská liga, Krátky Proces, Tři sestry, My-lai and Hubert Macháně.

\footnotetext{
3 Even in 2012-2014, Bílá liga (White League) a song on Orlík's second album, ranked among the ten most often played songs on Czech jukeboxes (Daniel, 2016).
} 
After 1992 many bands of this sort were formed, shaping opinions among Slovak skinheads (Kupka, Laryš, \& Smolík, 2009; Milo, 2004).

The original symbiosis between punkers and the racist skinheads soon came to an end as the increased supply of information from the West led to the two subcultures being more precisely defined, and many punkers began to follow the more sophisticated anarchism and other extreme left-wing groups (Mareš, 2003).

Despite the continual minor conflicts between punkers and skinheads there were no major politically motivated clashes until 30 May 1991, the day of an anarchist demonstration against the General Jubilee Exhibition. The purpose of the demonstration was, apart from protesting against the exhibition, to protest against a police raid 15 days earlier (15 May 1991) that had ended in a similar anarchist demonstration at the Exhibition Grounds with battles between the anarchists and the policemen. The anarchists thought the police intervention inadequate. The anarchist demonstration at the Exhibition Grounds was attacked by a group of Neo-Fascist skinheads from the National Fascist Community headed by the then popular Procházka brothers. The conflict resulted in an anarchist being severely injured. This was a significant moment in the relationship between the Czech anarchists and the radical right-wing skinheads. From that moment on the aversion developed into open animosity with verbal and physical conflicts becoming common (Bastl, 2001; Vávra, 2017). Another significant factor was the racist or politically motivated murders committed by Fascist skinheads, with the victims including two individuals connected to subcultures close to anarchism and anarchist ideas: Filip Venclík, singer of the punk band Rusko [Russia] (murdered on 5 September 1993), and Zdeněk Čepela, member of the Tanvald Anarchistic Association (murdered on 5 August 1994) (cf. Tomek \& Slačálek, 2006). These incidents and the skinhead subculture in general were also covered by anarchist and punk magazines (A-kontra, 1992; 1995).

Music bands were also significant in shaping the world outlook of the skinheads. There were several dozen bands from the 1990s on, significantly influenced by their foreign idols, their themes and so on (for details see Mareš, 2003; Rataj, 2001).

Another theme discussed in connection with the skinheads (mainly the extreme rightwing) was the symbols (runes, tattoos, Celtic crosses) skinheads used, which attracted the attention of the Czech and Slovak security forces ${ }^{4}$ (and found their way into documents ${ }^{5}$ ), as did the violent attacks (Grün, 1997; Chmelík, 2000, 2001; Danics, 2002; Černý, 2005, 2008; Smolík, 2016).

Until the mid-1990s, the political ideas in the subculture remained more or less undefined. As the subculture evolved even apolitical (meaning non-racist) skinheads began to emerge. Some scholars put the number of skinheads in the 1990s at around 4,000 in the Czech Republic, and more than 250 in Slovakia (Cotter, 1999).

\footnotetext{
4 It is worth mentioning that the "Slovak legislation", as worded in $\$ 422$ (2) of the Criminal Code of 2005, allowed action to be taken against the use of vicarious symbols (Mareš \& Výborný, 2013; Ministry of Interior of the Slovak Republic 2016, p. 45).

5 From the mid-1990s the "skinhead issue" featured significantly in the Reports on Extremism in the Czech Republic (Smolík, 2016).
} 
Politics played an important role in distinguishing between the various groupings within the subculture. Skinheads attracted greater attention from the mass media, which led to social condemnation of their acts (influenced by the media for the most part). An anti-Roma position was also attempted in the Czech Republic by the SPR-RSC and the NationalSocialist Movement of Europe and other similar organisations ${ }^{6}$ in Slovakia (Milo, 2004).

In the 1990s, an organisation called Bohemia Hammerskins (BHS) occupied an important position. It was active in 1993-1996, when it was the leading organisation of the Czech NS skinhead scene. Its activities were mainly aimed at provoking interventions by the state security forces. In 1997 Blood \& Honour Division Bohemia (BHDB) took over as leaders of the Neo-Nazi skinhead scene in the Czech Republic (Bastl, Mareš, Smolík, \& Vejvodová, 2011; Mazel, 1998).

Another example worth mentioning is a militant organisation called National Resistance, a branch of Prague-based Blood \& Honour Division Bohemia that was part of the scene in around 1998 (for more details see Mareš, 2003).

Following attempts to organize skinheads around nationalist sentiment and an emphasis on Hussite (Calixtine) traditions, most members began adopting racist, fascist or national socialist positions and attitudes in the first half of 1990s (Daniel, 2016; Milo, 2004; Vávra, 2017).

In the 1990s, the fervent nationalism of the skinheads and especially the extreme violence and street racism began to be a problem. Earlier on, during the rapid political changes of 1989-1990, with national reconciliation symbolised in the joint Czecho-Slovak national anthem sung by Karel Gott and Karel Kryl, Marta Kubišová and Hana Zagorová in city squares decorated with Czech flags and shown on TV, alternating with a video clip called Truth Wins by hard-rock band Tublatanka, the excessive patriotism may have been relativised by public opinion (Daniel, 2016). Another problem was the violent attacks against minorities, which attracted widespread media coverage. These included for example the murder of a Czech Roma citizen, Tibor Berki, in Žd’ár nad Sázavou in 1995 and the murder of Sudanese student Hassan Elamin Abdelradi in 1997 (Daniel, 2016; Mareš, 2003). These attacks were also reflected in political speeches. Both Václav Klaus (former Czech President and Prime Minister) and Miloš Zeman (former Czech Prime Minister and current Czech President) strongly rejected the skinhead culture, with Zeman calling for a complete ban on the skinhead movement (Daniel, 2016). In addition to the deaths, there were many other attacks and clashes, some of which ended in people being injured (Mareš, 2003).

On the other hand, some skinheads engaged in "political activism", organising demonstrations (for example against drugs) or establishing civic associations (Mareš, 2018).

The organisation with the widest media coverage was the National Alliance (NA), dissolved by the Ministry of Interior of the Czech Republic on 31 March 2003. It had been active since the late 1990s. It was dissolved because it propagated holocaust denial and incited racial intolerance in its magazine Vlajka (Flag) and at gatherings organised by the NA

\footnotetext{
6 In the early 1990s, the Association for the Republic-Republican Party of Czechoslovakia (SPR-RSČ) was the party many skinheads supported and voted for; moreover, they also attended its demonstrations, acting as a kind of "natural bodyguard". The party leader, Miroslav Sládek, was a charismatic figure and skilled speaker and the materials issued by SPR-RSC (mainly Republika, a newspaper) often commented on skinhead activities (see Mazel, 1998, pp. 215-219).
} 
(Černý, 2005, p. 156). The Vlastenecká Liga (Patriotic League), a Calixtine-type skinhead group, was officially registered as a civic association on 19 November 1993, although it had begun forming much earlier. The history of the VL began with the idea of setting up a single organisation for the Calixtine skinheads, a group of Czech skinheads that drew their ideas from the lyrics of Orlík, the first major Czech skinhead music band, concerning the martial heritage of the Hussite movement (Bastl, Mareš, Smolík, \& Vejvodová, 2011; Mareš, 2003). Skinheads followed and participated in events held by the Vlastenecká fronta (Smolík, 2013a). For many, the Vlastenecká fronta was an organisation through which they could obtain "political experience" (Mareš, 2003, p. 282).

J. Charvát (2007, p. 143) defines these organisations as "para-political" groups, and points out they were often the forerunners of extreme right-wing political entities.

At that time the terms "skinhead" and "Neo-Nazi" were used synonymously by the public (Gřivna, Scheinost, Zoubková et al., 2014). This was despite the skinhead subculture lacking any kind of homogeneity and including various types or groups of skinheads, often distinguished by political attitude or ideological preference.

In the early 1990s, the skinhead subculture attracted the attention of not only the security forces but also psychologists and sociologists. P. Sak and K. Kolesárová (2004) conducted a sociological survey and observed that young people shared the views of the skinhead subculture in the 1990s but that after that they became increasingly unpopular. Their interpretation was that the diminishing impact of the skinhead subculture on the young generation was probably a consequence of the skinheads propagating issues that were not of interest to young people and the same applied to their political actions. Further surveys among Czech youth (16-18 years of age) also revealed the level of skinhead popularity. For $3.6 \%$ of the boys surveyed and $2.8 \%$ of the girls surveyed the SHARP skinheads were most popular (see also Bastl, 2001). While right-wing skinheads were favoured by $4.1 \%$ of the boys and $1.6 \%$ of the girls (Holas, 2013, p. 47).

A similar sociological survey among elementary and secondary school students in Slovakia, which looked at social media and website interest in skinheads, found that $16 \%$ of respondents (of 2,400 respondents) searched for websites related to the subcultures (skinheads, punk), and $4.5 \%$ of them claimed to be "skinhead fans". The survey also found that $1.2 \%$ of the sample of young Slovaks said they belong to the skinhead subculture (Šrámek, 2013).

Quantitative research identified the main leisure-time activities of the apolitical skinhead subculture in the Czech Republic. The survey showed that most of the respondents spent their leisure time doing sport, including combat sports (box, kick-box, Thai-box). Other leisure-time activities included music, going to the pub, spending time with the family, watching football matches, reading and playing computer games (Smolík, 2013b).

Psychological research based on focus groups identified the basic themes that were important to skinheads, such as a fear of the future, self-concept, close relationships, leisure time, perceptions of minorities (especially the Roma minority) and social standards in general. The research was conducted using a literary text containing the main themes expressed by members of this subculture in the late 1990s (for example their relationship to the Roma minority, parents, politics). Strong emotional affinities between the skinheads were also identified (Navrátil, Čermák, \& Horoščák, 2000). 


\section{Skinhead typology}

The skinhead typology in the Czech Republic and in Slovakia is determined by political preferences or at least attitudes to politics, society and selected themes such as national minorities, migration, globalisation, nationalism, geopolitical changes and democracy (Mikulčíková, 2010). In Czechoslovakia, as in other post-communist societies, this subculture established itself in the late 1980s when the old generation were replaced by the new generation.

Skinheads underwent a strong internal restructuring especially regarding ideological orientation, music style or links to other subcultures. The only remaining unifying features were shaved heads and other imagery, and sometimes violent behaviour. However, it is difficult to produce an accurate skinhead typology, due to the frequent ambiguity, interconnections (but also mutual hostility and blurred boundaries between enemies), the stormy development of all the various groups and the situations in different countries.

In the case of the Czech Republic, skinheads were identified on the basis of their political preferences, with the typical uniformity of the skinhead image being preserved. The various skinhead groups were characterised by fighting, alcohol, supporting football teams, and a strong resentment of the hippies and alternative youth groups of the late 1980s. They also viewed the relatively widespread heavy-metal subculture with negativity.

One of the groups in the early 1990s was more traditionalist, emphasizing patriotism, labour roots, anti-communism and a distrust of transformation and non-transparent politics. The term "traditionalist" has a double meaning here. It was first used to distinguish this group from the racist skinheads, and then in reference to its relationship to the historic first-generation skinhead gangs (from roughly 1966-1969) that established the skinhead subculture (Sarabia \& Shriver, 2004).

There is an overlap between the traditionalists and the Oi! skinheads, mainly through their identity with street punk and the Oi! roots in late 1970s Great Britain, which brought them fairly close to another important subculture of the time, punk rock, characterised by a resentful approach to the petty bourgeois consumer society. A number of Oi! skinheads and traditionalists referred to themselves as patriots, rejecting national socialism on the one hand but not excluding violence against immigrants, drug addicts and criminals on the other. This group of skinheads adopted the traditional fashion of the English skinheads, resulting in imports of typical brands such as Lonsdale, Fred Perry, Ben Shermann and Dr. Martens (Mareš, 1997; Smolík, 2017). Unlike in other countries, the Czech Republic of the early 1990s - had no SHARP skinheads (Skin Heads Against Racial Prejudice). This group only appeared in the Czech Republic after 1996, when it declared itself to be anti-racist and antifascist (Mazel, 1998).

Another, quite marginal part of the skinhead subculture was the red skins, who subscribed to left-wing ideologies (communism, Trotskyism or anarchism), something that had been completely out of the question in the 1990s. They had no official (political) platform though (Mazel, 1998). This was partly because of the previous era and the fact that "democratising" society rejected left-wing ideals, which had been completely discredited by the previous regime. These two groups did not assert themselves more pronouncedly until the late 1990s when the first communities of left-leaning and anti-Fascist skinheads were formed. 
In the early 1990s, the media and police identified the skinhead subculture above all with extreme-right-wing (racist) members (Mareš, 2008). The Czech music scene then began to evolve, with groups defining themselves as white power bands (Mareš \& Smolík, 2012; Smolík, 2013b; Smolík, 2017).

The social conditions were right for the skinhead subculture to develop, in a society that defined itself as "democratic" with a strong anti-communist attitude, and where patriotism provided a particular sort of certainty and cohesion among adolescents. The ideological background of the skinhead subculture was weak at that time, mostly represented by an inconsistent combination of racial prejudice, superficial knowledge of extreme right-wing ideology and sympathy for Czech collaborators during World War II (Marě̌, 2003).

At present, the skinhead culture is in retreat from the political scene because of recent changes in society and culture in general. The first factor is demographic change which has led to fewer adolescents compared to in the early 1990s (the early 1990s generation was a baby-boom generation known as "Husák's Children"). The second major factor was a change in the music and life styles of the young generation (rap, dance music etc.), which reduced the potential base for the skinhead subculture. Another significant factor was the criminalisation of the extreme right-wing skinhead subculture and Czech and Slovak security forces targeting the organisations and skinhead-based ideas (Smolík, 2013b).

In Slovakia, there were similar groups to those in the Czech Republic. D. Milo (2004) defines the nationalist group (as exhibiting strong resentment against the Hungarians, and emphasising morals and Christian values), the Neo-Nazi group (was defined by its adherence to national socialist ideology, anti-Semitism, racism etc.), and SHARP skinheads (Skin Heads Against Racial Prejudice) (sometimes apolitical) who had very few supporters in the 1990s. The Neo-Nazi group subscribed to the heritage of the fascist Slovak State, glorifying A. Mach, A. Hlinka and J. Tiso. Thus, as early as the 1990s, a number of skinhead-based organisations had been founded, but these were often of a fleeting nature, or had marginal significance for the extreme-right (Kupka, Laryš, \& Smolík, 2009). The symbols mentioned earlier often played an important role, distinguishing the various groups within the subculture. The basic image and fashion (popular brands such as Lonsdale, Fred Perry, Ben Sherman, Dr. Martens, Alpha Industries) were shared by most of the subculture groups (Ridgers, 2014). In the 1990s particular clothing brands, symbols ${ }^{7}$, applications ${ }^{8}$, abbreviations but also hairstyles (length and cut) were also important. Music was another major means of identification, and indicated for example by T-shirts featuring the name of a particular music band.

These days the Czech, as well as Slovak, skinhead scene is fragmented owing to the political orientation (and engagement) of its members, who identify with: a) extreme rightwing politics (nationalist socialism); b) traditionalism (patriotism and the classical themes

\footnotetext{
7 The basic purpose of a symbol is to convey information (Černý, 2008). Symbols are usually open and manifesting. Symbols may vary, but include tattoos, graffiti, coded numerical symbols, signs, acronyms and gestures (Vegrichtová, 2017). Symbols are thus a means of group identity formation within the subculture (Vegrichtová, 2018).

8 According to H. Kubátová (2010) patches indicated which skinhead faction a person belonged to and their position in the skinhead hierarchy.
} 
of the original skinhead subculture); c) extreme left-wing politics (Trotskyism, Marxism, communism and anarchist ideas) (Smolík, 2016).

\section{Magazines of skinhead subculture: pre-internet era}

Like similar subcultures of the time the skinhead subculture used "samizdat" magazines, called "zines". These were mostly A5 zines of A5 format typed on a typewriter (Bihariová, 2011). These "home-made" magazines were an important means of sharing information among skinhead followers. One of the first accounts of the skinhead subculture was an alternative underground magazine called Vokno [Window] (see also Vokno, 1990).

In the Czech Republic, the first zines connected with punk or skinhead subculture (or both, in the early 1990s) appeared in 1990. Although the zines usually targeted a single subculture, their focus was usually wider (punk, oi, ska etc.). Zines probably reached their peak in 1994-1997; nonetheless, new zines continue to appear even today and older titles are lent and copied (Mareš, 2003).

In the Czech Republic there were several dozen zines, see for example Čech, Patriot, Hubert, Nový rád, The Hammer News, Skinhead Zone, Fénix, Riot News, White Rock Music, Clockwork Legion, SkinRead, Boots \& Braces, Bootweiser, Silesia, Way to Victory, AntiHero, Nová Evropa, Real Enemy, Národní stráž, Skinformátor, Der Stürmer, Skinhead Pride, Rebel, Hlas národa, Svoboda and others (Mareš, 2003; Mazel, 1998; Smolík, 2017; see also Fénix, 1993; Rebel, 1996; Skinhead Pride, 1996; Svoboda, 1996). For apolitical skinheads there were magazines such as Bulldog, Messenger, Sunrise, Ulice, Rytír and Riot News. This last category was aimed at Czech SHARP skinheads (Bastl, 2001).

In addition to these zines there were also Calixtine magazines (for example Český štít, Práče or later Houfnice9), often connected with the Vlastenecká liga of the National Patriotic Union (Houfnice, 1999; Mareš, 2003; Mazel, 1998).

Even more interesting, there were zines specifically designed for girls, such as Bílá Růže and Skinheadgirl (Bílá růže, 1996; Skinheadgirl, 1996).

In Slovakia in the 1990s, there were several dozen zines focusing primarily on the Slovak skinhead scene, including Árijský boj, Biely boj, Gardista, White Victory, Rodobrana, and Aryan Law (Mazel, 1998; Milo, 2004).

By 2000, websites and social networks had begun appearing and these became the main communication channel of all the groups in the subculture. The expansion of the internet accelerated communication within the subculture, and led to the wider propagation of the propaganda of the various political organisations; however, these were separate from the skinhead subculture (Munková, 2008). There are many skinhead zines reflecting the current Czechoslovak scene (Chuligán, 2005; Real Enemy, 2010; 2012; 2013; 2015; 2017), which have a far more professional graphic layout compared to the early 1990s. Some zines even publish interviews with the main figures from the 1900s (Retro Skins, 2017).

\footnotetext{
9 This magazine provided detailed information about activities of the skinhead organisations, although the publisher, the National Patriotic Union, detached itself from the skinhead subculture (for details see Houfnice, 1999).
} 
The zines enabled the Czechoslovak skinhead subculture to create a unique network for sharing opinions, ideas and thinking, and this strongly contributed to the development of the subculture's specific identity. The zines also shared experiences from abroad and developed their own particular style.

We will now look at two zines of the period of interest, including the first three issues of Patriot (published in Trutnov) and Hubert (published in Žaclér).

Patriot portrayed itself as "alternative media" for Czechoslovak skinheads. The first Patriot issue contained interviews with Czech and foreign music bands (see for example Buldok, Execute, Skullhead), information about tattoos and fashion and the first part of a history of the Ku Klux Klan (see Patriot, 1/1992). The second issue contained information on new magazines for skinheads, interviews with bands (Squadron, The Battle Zone), a critique of the European integration process (especially, the European Union Treaty, 1992), interviews with publishers of skinhead magazines in other countries (Belgium, the USA) and the continuation of the history of the Ku Klux Klan (see Patriot, 2/1992). The third issue again featured interviews with music bands (Diktátor, Konkwista 88), and an interview with the publisher of a foreign zine. Information about skinhead fashion was a key part of the zine (Patriot, 1/1993).

The first issue of Hubert introduced British bands such as the Angelic Upstarts and The 4 Skins, the Colombian skinhead band Sociedad Violenta and Böhse Onkelz from Germany. It also published reviews of foreign music recordings (from bands such as The Oppressed, Last Resort) and information about a girls' skinhead band called Jen žádnou paniku [No panic, please] and a report on a concert in Nové Město nad Metují (Orlík, Tři sestry, Jen žádnou paniku, Nátěrová hmota) in October 1990 (see Hubert 1/1990).

The second issue introduced the bands Peter and the Test Tube Babies, Violent Storm, Plastic Surgery, Blitz and Red Alert, and also contained reviews of foreign music recordings (from Business, Infa-Riot, Anti-Heroes) and information about a skinhead meeting in Germany (see Hubert 2/1991).

The third issue included in-depth coverage of the bands Business and Madness and a translated article about a music festival in London. The interviews included one with a skinhead band called Valašská liga. The zine also reported on punk concerts in Czechoslovakia, in particular performances by the Exploited and Toy Dolls in Prague in 1991. And there were also reviews of music recordings of foreign music bands (Skullhead, Condemned 84). There was also an extensive account of the German skinhead scene and the various groups within the subculture. The third Hubert issue contained short reports of a skinhead concert at Bzenec (see above) and one in Valašské Meziřríčí (see Hubert 3/1992). A relatively large proportion of all these zines were far removed from politics and ideology, i.e. anarchists or communists.

\section{Results}

The history of any subculture includes the history of changes in the subculture's standards, values and beliefs (Wood, 1999). This history may be viewed through testimonies from inside the subculture, based on the printed materials produced during the subculture's 
existence. In our case, the materials are the skinhead zines published since the early 1990s and created by skinhead members.

The zine articles were predominantly about the music of the subculture (interviews with bands, reports on concerts or skinhead gatherings), but there were also comments, notes and critical views of the political scene (and of drugs, anarchism, communism, postmodern themes, media, European integration). Each zine was a unique reflection of the local skinhead scene.

The zines described the activities of the skinhead gangs, including concerts and meetings and contained information from abroad. Thus, the zines clearly contributed to the creation of the Czechoslovak skinhead scene. M. Mareš (2003) correctly says that the zines were primitive, but that was typical of the genre and of the era; in the early 1990s modern computer technology did not yet exist. Between 1988 and 1992 the small skinhead groups grew with the subculture expanding to several thousand followers. The skinheads formed different (often antagonistic) groups, creating an informal network of relations shaped not just by their zines but also by the concerts, demonstrations and typical visual style (often with its own symbols, rituals etc.).

In the 1990s, there were three main types of zines. The first was restricted to the subculture (the fashion, football, music etc.). The second type of zine covered foreign skinhead organisations and right-wing movements. The last type focused on foreign racist and anti-Semitic organisations (e.g. describing the Ku Klux Klan and the Czech historical organisation Vlajka).

\section{Conclusions and discussion}

In the late 1980s, the skinhead scene underwent a number of transformations: from the initial (logical) connection with the punk rock subculture to the radical political groupings based on the skinhead subculture of the late 1990s. There was also the distinct group of Calixtine skinheads with their claim to Hussite heritage.

The initial activities of the subculture, mainly organising demonstrations and concerts, become more "political" including attempts at trans-nationalising the Czech skinhead scene (Polášková, 2001). After 1989, all the youth subcultures that had existed under the "real socialist" regime underwent rapid development. There were also significant foreign influences, information and direct meetings between followers and subculture leaders. The skinheads mainly developed contacts with their counterparts in Great Britain and Germany.

As O. Daniel (2016) has correctly pointed out, the Czech post-socialist skinheads tended to merge into the racist wing of the subculture established in Western Europe at the turn of the 1970s and 1980s. P. Černý (2008) has stated that the skinheads cannot be considered a movement in their own right. The skinhead subculture is a traditional subculture with its own communication channels, the zines of the late 1980s and early 1990s. This article has looked not only at the various groups within the skinhead subculture in what was Czechoslovakia but also at the traditional themes of this subculture based on a description of the zines.

It would be worth analysing all the zines, since they are considered to be among the few materials available to historians and political scientists. 


\section{References}

Bastl, M. (2001). S.H.A.R.P. Skinheadi proti rasovým předsudkům [Skinheads against racial prejudices]. Stréedoevropské politické studie 3(3).

https://journals.muni.cz/cepsr/article/view/3868

Bastl, M., Mareš, M., Smolík, J., \& Vejvodová, P. (2011). Krajní pravice a krajní levice v $\check{C} R$ [The far right and the far left in the Czech Republic]. Prague: Grada.

Bihariová, I. (2011). Vývoj pravicového extrémizmu na Slovensku v rokoch 1989-2011. Bratislava: Ludia proti rasizmu.

Botsch, G. (2012). From skinhead-subculture to radical right movement: The development of a 'National Opposition' in East Germany. Contemporary European History, 21(4), 553-573.

Braunová, D. (2014). David Matásek: Spravedlivý svět začíná na vlastním dvorku [A just world begins in one's own backyard]. Magazín Práva, November 15, 2014, 4-8.

Černý, P. (2005). Politický extremismus a právo [Political extremism and law]. Prague: Eurolex Bohemia.

Černý, P. (2008). Právní ochrana před extremismem [Legal protection against extremism]. Prague: C. H. Beck.

Charvát, J. (2007). Současný politický extremismus a radikalismu [Contemporary political extremism and radicalism]. Prague: Portál.

Chmelík, J. (2000). Symbolika extremistických hnutí [The symbolism of extremist movements. Prague: Armex.

Chmelík, J. (2001). Extremismus a jeho právní a sociologické aspekty [Extremism and its legal and sociological aspects]. Prague: Linde.

Cotter, J. M. (1999). Sounds of hate: White power rock and roll and the neo-nazi skinhead subculture. Terrorism and Political Violence, 11(2), 111-140.

Danics, $\breve{S}$. (2002). Extremismus hrozba demokracie [The threat of extremism to democracy]. Prague: Police History.

Daniel, O. (2016). Násilím proti „,novému biedermeieru“. Subkultury a většinová společnost pozdního státního socialismu a postsocialismu [Violence against the "New Biedermeier". Subcultures and majority society of late state socialism and post-socialism]. Př́ibram: Pistorius \& Olšanská.

Gilbert, P. (2007). Clash: smrt nebo sláva [Clash: death or glory]. Prague: Volvox Globator.

Glasper, I. (2010). Burning Britain: historie punku ve Velké Británii 1980-1984 [Burning Britain: The history of punk in the UK 1980-1984]. Prague: Volvox Globator.

Gřivna, T., Schneinost, M., Zoubková, I. et al. (2014). Kriminologie [Criminology]. Prague: Wolters Kluwer.

Grün, A. (1997). Kř́žz: teologický a duchovní význam symbolu naděje [The Cross: The theological and spiritual meaning of the symbol of hope]. Kostelní Vydří: Karmelitánské nakladatelství.

Hamm, M. S. (1993). American skinheads: The criminology and control of hate crime. Westport: Praeger.

Hendl, J. (2005). Kvalitativní výzkum: základní metody a aplikace [Qualitative research: Basic methods and applications. Prague: Portál.

Holas, J. (2013). Politický radikalismus a mládež [Political radicalism and youth]. Prague: Institut pro kriminologii a sociální prevenci.

Konáš, J. (2005). Nanebevzetí Daniela Landy. Mladý svět, 47(8), 16-19.

Kromschröder, G. (1986). Holohlavci, to jou, pane, chlapci...[Skinheads, they, sir, are boys]. 100+1 zahraniční zajímavost, 32(18), 9-12.

Kubátová, H. (2010). Sociologie životního způsobu [Sociology of lifestyle]. Prague: Grada Publishing.

Kupka, P., Laryš, M., \& Smolík, J. (2009). Krajní pravice ve vybraných zemích střední a východní Evropy: Slovensko, Polsko, Ukrajina, Bělorusko, Rusko [The far right in selected countries of 
central and eastern Europe: Slovakia, Poland, Ukraine, Belarus, Russia] Brno: Masarykova univerzita.

Mareš, M. (2003). Pravicový extremismus a radikalismus v ČR [Right-wing extremism and radicalism in the Czech Republic]. Brno: Barrister \& Principal.

Mareš, M. (2008). Pravicový extremismus v České republice [Right-wing extremism in the Czech Republic]. CevroRevue. Casopis pro př́znivce pravicové politiky, 10(10), 5.

Mareš, M. (2018). Vybrané problémy soudobých extremistických shromáždění v ČR [Selected problems of contemporary extremist assemblies in the Czech Republic]. In Social Care Department, Magistrate of the City of Brno. Kriminalita, prevence kriminality a společnost (pp. 65-75). Brno: Magistrate of the City of Brno.

Mareš, M., \& Smolík, J. (2012). White power music and interconnected issues in the Czech Republic, 1999-2011. In A. Shekhovtsov \& P. Jackson (Eds.), White power music. scenes of extreme-right resistance (pp. 71-83). Ilford, Northampton: University of Northampton.

Mareš, M., \& Výborný, Š. (2013). Militantní demokracie ve střední Evropě [Militant democracy in central Europe]. Brno: Centrum pro studium demokracie a kultury.

Mareš, R. (1997). Skinheads: subkultura zničená ideologií [Skinheads: A subculture destroyed by ideology]. Nová prítomnost, 3(4), 2-6.

Marshall, G. (1994). Spirit of '69: A skinhead bible. Dunoon: George Marshall.

Mazel, M. (1998). Oponenti systému. Přehled radikálních a extremistických organizací v České republice. In P. Fiala (Ed.), Politický extremismus a radikalismus v České republice. [System Opponents. Overview of radical and extremist organizations in the Czech Republic. Political extremism and radicalism in the Czech Republic (pp. 117-277)]. Brno: Masaryk University.

Mikulčíková, A. (2010). Pravicový extrémizmus v Spolkovej republike Nemecko: príčiny, podoby, prejavy [Right-wing extremism in Germany]. Banská Bystrica: UMB.

Milo, D. (2004). Rasistický extrémizmus v Slovenskej republike [Racism and extremism in the Slovak Republic]. Bratislava: L'udia proti rasizmu.

Munková, E. (2008). Čeští neonacisté se učí užívat zákon. Př́ítomnost. [Czech neo-nazis learn to use the law. Presence]. Politický a kulturní čtvrtletník, Spring 2008, 20-23.

Navrátil, M., Čermák, I., \& Horoščák, M. (2000). Životní styl brněnských skinheads: Metoda focus group. In I. Čermák \& M. Miovský, (Eds.), Kvalitativní výzkum ve vědách o člověku na prahu tretího tisíciletí (pp. 72-87) [Lifestyle of skinheads in Brno: Focus group method. In I. Čermák \& M. Miovský (Eds.), Qualitative research in human science on the threshold of the third millennium (pp. 72-87)]. Boskovice: Nakladatelství Albert.

Peknušiaková, E. (2014). Popkultúra v slovenskom mediálnom prostredí - mládežnické subkultúry 20. storočia a ich prienik do súčasnosti (prezentácia módnej vlny emo v slovenskom mediálnom prostredí). In M. Ballay, K. Gašová, K., \& V. Kudláčová (Eds.), Minority v systéme kultúry. Zborník z medzinárodnej vedeckej konferencie (pp. 297-307). Nitra: Univerzita Konštantína Filozofa v Nitre.

Polášková, A. (2001). Skinheadi, bonehedi a ti ostatní [Skinheads, boneheads, and the others]. Listy, 31(4), 73-76.

Policejní prezidium ČR. (1993). Charakteristika extremistů a extremistických skupin [Police Presidium of the Czech Republic. Characteristics of extremists and extremist groups]. Prague: Criminal Police Headquarters.

Rataj, J. (2001). Je pořád hezká, ta naše písnička česká? Ze skinheadské politické voničky [Is our Czech song still beautiful? From a skinhead political outfit]. Listy, 31(1), 11-16.

Ridgers, D. (2014). Skinheads 1979-1984. London: Omnibus.

Ridgeway, J. (1990). Blood in the face: The Ku Klux Klan, Aryan Nations, Nazi Skinheads, and the Rise of a New White Culture. New York: Thunders's Mouth Press.

Sak, P., \& Kolesárová, K. (2004). Mládež na křižovatce: sociologická analýza postavení mládeže ve společnosti a jeji úlohy v procesech evropeizace a informatizace [Youth at the crossroads: 
Sociological analysis of the status of youth in society and its role in Europeanization and informatisation processes]. Prague: Svoboda Servis.

Sarabia, D., \& Shriver, T. E. (2004). Maintaining collective identity in a hostile environment: Confronting negative public perception and factional divisions within the skinhead subculture. Sociological Spectrum, 24(3), 267-294.

Smolík, J. (2006). Extremismus subkultur mládeže? [Extremism of youth subcultures]? Rexter, 5 (1)]. http://www.rexter.cz/extremismus-subkultur-mladeze/2006/05/01/

Smolík, J. (2013a). Krajněpravicové politické strany v zemích V4: historie a současnost [Right-wing political parties in V4 countries: history and present]. Sociológia - Slovak Sociological Review, 45(4), 385-410.

Smolík, J. (2013b). Subkultura skinheads v České republice. In G. Lubelcová \& R. Džambazovič (Eds.), Sociálna patológia optikou sociologického skúmania [Skinhead subculture in the Czech Republic. In G. Lubelcová \& R. Džambazovič (Eds.), Social Pathology in view of sociological research] (pp. 360-371). Bratislava: Stimul.

Smolík, J. (2016). Kde ti všichni skíni jsou? Obsahová analýza Zpráv o problematice extremismu na území ČR v letech 1997-2013 [Where are all the skins? Content analysis of reports on the issue of extremism in the Czech Republic in 1997-2013]. Kontakt, 18(2), 127-133.

Smolík, J. (2017). Subkultury mládeže: sociologické, psychologické a pedagogické aspekty. [Youth subcultures: Sociological, psychological and pedagogical aspects]. Brno: Mendel University.

Sobotková Nielsen, V. et al. (2014). Rizikové a antisociální chování v adolescence [Risk and antisocial behavior in adolescence]. Prague: Grada Publishing.

Šrámek, L. (2013). Postoj mládeže k prejavom extrémizmu. In R. Štefančík et al. Pravicový extrémizmus a mládež na Slovensku (pp. 192-211). Brno: Tribun EU.

Tomek, V., \& Sláčálek, O. (2006). Anarchismus: svoboda proti moci [Anarchism: freedom against power]. Prague: Vyšehrad.

Vaněk, M. (2010). Byl to jenom rock'n'roll? Hudební alternative v komunistickém Československu 1956-1989 [Was it just rock'n'roll? Musical alternative in communist Czechoslovakia 1956-1989]. Prague: Academia.

Vávra, F. (2017). Těžký boty to vyřešej hned. Skinheads v Praze na konci 80. let a začátku 90. let [Heavy boots, solve it now. Skinheads in Prague in the late 1980s and early 1990s]. Prague: FIVA.

Vegrichtová, B. (2017). Gangy: vězeňské, pouliční a motorkářské [Gangs: Prison, street and biker]. Prague: Grada Publishing.

Vegrichtová, B. (2018). Symbolika kriminálníh tetování (2 ${ }^{\text {nd }}$ ed.). [Symbolism of criminal tattoos]. Plzeň: Aleš Čeněk.

Wood, R. T. (1999). The indigenous, nonracist origins of the American skinhead subculture. Youth and Society, 31(2), 131-151.

Worley, M. (2013). Oi! Oi! Oi!: Class, locality, and British punk. Twentieth Century British History, $26(1), 1-31$.

Youngová, C. (2017). Módní kmeny. Styl subkultur [Fashion tribes. Subculture style]. Prague: Slovart.

\section{Materials}

A-kontra. Zpráva alternativních aktivit. (1992), vol. II, no. 8-9. [A-contra. Alternative Activities Report. (1992) vol. 8-9.]

A-kontra. Zprávy alternativních aktivit. (1995), vol. V, no. 3-4. [A-contra. Alternative Activity Reports. (1995) vol. 3-4.]

Bílá růže. 1996, no. 1. [White Rose. 1996, no. 1.]

Fénix. 1993. no. 6. [Phoenix. 1993. no. 6.]

History of Skinheads. Vokno, 1990, pp. 88-91. 
Houfnice. Ústřední zin občanského družení Národně vlastenecký svaz. 1999. no. 3. [Howitzer. The Central Zin of the National Patriotic Union Civic Association. 1999. no. 3.]

Hubert. Žaclér. 1990, no. 1.

Hubert. Žaclér. 1991, no. 2.

Hubert. Žaclér. 1992, no. 3.

Chuligán. Streetpunk zine for all skinheads, punx, rudeboys. 2005, no. 2.

MV SR. 2016. Symbolika využívaná extrémistickými a radikálními skupinami. Bratislava, MV SR, 2016, p. 123. No ISBN.

Patriot. Trutnov. 1992. no. 1.

Patriot. Trutnov. 1992, no. 2.

Patriot. Trutnov. 1993, no. 3.

Real Enemy. 2010, no. 9.

Real Enemy. 2012, no. 13.

Real Enemy. 2014, no. 14.

Real Enemy. 2014, no. 14.

Real Enemy. 2015, no. 16.

Real Enemy. 2017, no. 17.

Rebel. 1996, no. 3.

Retro Skin. 2017. Do It Yourself zine. Unnumbered.

Skinheadgirl. 1996, no. 3.

Skinhead Pride. 1996, no. 4.

Svoboda. 1996, no. 4. [Freedom. 1996, no. 4.]

Vokno. 1990, no. 18.

Faculty of Regional Development and International Studies,

Mendel University in Brno

třída Generála Píky 2005/7,

61300 Brno - Černá Pole,

Czech Republic

Email: josef.smolik@mendelu.cz

Faculty of Regional Development and International Studies, Mendel University in Brno.

třída Generála Píky 2005/7,

61300 Brno - Černá Pole,

Czech Republic

Email: petr.novak@mendelu.cz 